\title{
Desafios do próximo Governo Estadual na área Sócio-Econômica*
}

\author{
Lucas Dezordi * \\ José Luis Oreiro ${ }^{* *}$
}

O desempenho da economia paranaense está diretamente relacionado à dinâmica econômica nacional. Nos últimos anos, o Paraná vem se destacando em relação aos demais estados da Federação nos seguintes itens: quinto maior gerador de riquezas, Produto Interno Bruto (PIB), total e industrial; quarto maior exportador de produtos; e sexto em geração de renda per capita. Neste sentido, ao se traçar uma análise focada nos desafios socioeconômicos do próximo governo, questões importantes de âmbito nacional devem ser discutidas. Primeiramente, a combinação perversa de juros elevados com apreciação significativa do câmbio nos últimos anos vem prejudicando o desempenho de atividades produtivas essenciais para o desenvolvimento do estado.

De acordo com o Instituto Brasileiro de Geografia e Estatística (IBGE), a produção industrial acumulada no primeiro semestre de 2006, em comparação ao mesmo período do ano anterior, caiu 3,8\% liderada principalmente pelos segmentos da madeira, de máquinas e equipamentos, de veículos automotores e de moveleiro. O câmbio valorizado, aliado a forte estiagem e a queda no preço das commodities, também influenciou negativamente o desempenho da agricultura, principalmente na produção de grão (soja e milho) nas safras de 2005/06.

Como conseqüência, a criação de empregos na indústria de transformação em 2005 foi de apenas 1,4\%, com reduções de vagas nas atividades têxtil, madeira, refino de petróleo e meios de transportes. Infelizmente, de acordo com o Caged/ MET e reportado por este jornal em 29 de setembro de 2006, a geração de empregos no Paraná está ficando mais preocupante, pois se compararmos o período de janeiro a agosto deste ano, em relação ao ano anterior, a criação de empregos formais caiu 5,99\%. Grande parte desta redução ocorreu e, pior, ainda está ocorrendo no interior do estado, fruto da crise agrícola.

Os setores da indústria e de serviços são as atividades que mais empregam no Paraná e em conjunto representam aproximadamente $72 \%$ do emprego formal. Uma característica marcante no estado é que grande parte desses empregos (mais de 60\%) é gerada apenas na

\footnotetext{
* Publicado no jornal "Gazeta do Povo" no dia 03/10/2006.

* Professor da FAE Business School. Endereço Eletrônico: ldezordi@,fae.edu

** Professor do Departamento de Economia da Universidade Federal do Paraná (UFPR). Pesquisador do CNPq e Coordenador do boletim de conjuntura Economia \& Tecnologia. Endereço eletrônico: joreiro@ufpr.br
} 
mesorregião metropolitana de Curitiba. Neste caso, observamos que o desenvolvimento socioeconômico do estado está concentrado em apenas um importante eixo. Essa característica explica, em certa medida, a concentração de riqueza observada no estado. Em comparação com regiões importantes, o Paraná apresenta um coeficiente de concentração de riqueza maior do que o observado no Rio Grande do Sul, Santa Catarina, São Paulo e Minas Gerais. Estudos recentes do Instituto Paranaense de Desenvolvimento Econômico e Social (Ipardes) indicam que o grau de pobreza (porcentual da população com rendimento per capita mensal inferior a meio salário mínimo) no Paraná é superior que os observados em todos os estados supracitados, acrescido o estado do Rio de Janeiro e empatado com Espírito Santo. O estudo destaca também que mais de $70 \%$ da pobreza no Paraná está localizada no interior e na zona rural.

Neste contexto, podemos destacar pelo menos três grandes desafios socioeconômicos para o próximo governo estadual, sem esgotar novas opções. Primeiro, melhorar e ampliar a presença do Paraná nas questões e projetos nacionais, buscando assim novas oportunidades de crescimento para o estado e para o Brasil. Segundo, diminuir as desigualdades socioeconômicas com estímulos em novos pólos de desenvolvimento, sendo fundamental ampliar os investimentos públicos e privados em infra-estrutura rodoviária, portuária, ferroviária, entre outros. Terceiro, criar políticas agrícolas estruturadas e focadas em uma dinâmica de longo prazo, com isso, fornecendo condições financeiras mais estáveis para os agricultores em períodos de crise, como a atual. 